\title{
Developmental Aspects of Renal Tubular Reabsorption of Water in the Lamb Fetus
}

\author{
JEAN E. ROBILLARD, JAMES R. MATSON, CHRISTINE SESSIONS, AND FRED G. SMITH, Jr.
}

Department of Pediatrics, University of Iowa Hospitals and Clinics, Iowa City, Iowa, USA

\begin{abstract}
Summary
The effects of intrauterine maturation on the tubular reabsorption of water by the fetal kidney was determined in $\mathbf{4 4}$ chronically catheterized fetal lambs divided in three groups. Fourteen fetuses were studied between 101 and 119 days, 13 between 120 and 130 days, and 17 between 131 and 142 days. The urinary flow rate increased $(P<0.01)$ when fetuses $<120$ days were compared to fetuses between 120-130 days of gestation. A 35\% increase in Uosm was found in fetuses over 130 days and was paralleled by significant increases in (U/P) iothalamate and $(U / P)$ osm ratios. An increase in (U/P) urea ratio in fetuses over 130 days correlated with an increase in $(U / P)$ iothalamate $(r=0.87)$. The $(U / P)$ ratios for $\mathrm{Na}^{+}$and $\mathrm{Cl}^{-}$were not correlated with fetal age and did not increase during gestation. The percent of filtered water excreted (V/GFR) was high before 120 days of gestation $(26.8 \pm 3.04 \%)$ and remained elevated in fetuses of $120-130$ days $(28.7 \pm 2.53 \%)$. After 130 days of gestation, it decreased significantly to $18.3 \pm$ $2.56 \%(P<0.05)$. Similarly, $C_{\mathrm{H}_{2} \mathrm{O}} / \mathrm{GFR}$ values were, respectively, $12.02 \pm 1.53$ and $13.18 \pm 1.46 \mathrm{ml} / \mathrm{min} / 100 \mathrm{ml} \mathrm{GFR}$ in groups of fetuses of less than 120 days and between 120-130 days; after 130 days $\mathrm{C}_{\mathrm{H}_{2} \mathrm{O}} / \mathrm{GFR}$ decreased significantly to $5.82 \pm 1.97 \mathrm{ml} / \mathrm{min} /$ $100 \mathrm{ml}$ GFR $(P<0.02)$. Cosm/GFR remained unchanged in all three groups of fetuses at $14.76 \pm 2.57,15.49 \pm 1.90$, and 12.51 $\pm 1.34 \mathrm{ml} / \mathrm{min} / 100 \mathrm{ml}$ GFR, respectively. The simultaneous significant decreases in $V / G F R$ and $C_{\mathrm{H}_{2} \mathrm{O}} /$ GFR without changes in Cosm/GFR in fetuses over 130 days suggest that the increase in Uosm in near-term fetuses represents an increase in free water reabsorption by the fetal kidney.
\end{abstract}

\section{Speculation}

The increase in free water reabsorption by the near-term fetal kidney may represent either an increase in end-organ responsiveness to arginine vasopressin or maturation of mechanisms involved in the buildup of the osmotic gradient in the fetal medulla or both.

Available information on the maturation process of the renal concentrating ability during fetal life is limited. Previous studies using exteriorized fetal preparations reported that fetal urine osmolality is usually hypotonic when compared to plasma $(3,6$, $13,23)$. Similar results were also described for urine formed by the human fetus (14). However, it was also observed in exteriorized fetal lamb (3) and fetal guinea pig $(5,15)$ preparations that hypertonic urine could be elaborated just before birth.

Using long-term fetal lamb preparations, Gresham et al. (8) described that fetal urine was predominantly hypotonic in respect to plasma osmolality when adequate time was allowed for the fetus to recover from the stress of surgery. However, both this latter study and previous studies using exteriorized fetal preparations utilized small numbers of animals and did not provide adequate information regarding the maturation process involved in tubular reabsorption of water during gestation.

Recently, Stanier (25) demonstrated in renal tissue from nearterm lamb fetuses, a steep intrarenal gradient for sodium. It was then suggested that the capacity of the fetal tubule to reabsorb filtered water may be increased in the last part of gestation. The present protocol was therefore designed to study, in vivo, the influence of fetal maturation on reabsorption of water by the fetal kidney during the last trimester of gestation.

\section{METHODS}

The fetuses of 44 pregnant sheep of Dorset and Suffolk mixed breeding were studied between 101-142 days of gestation (term being between 145-148 days). Fourteen fetuses were between $101-$ 119 days, 13 between 120-130 days and 17 between 131-142 days. Gestational ages were based on the induced ovulation technique $(2,10)$ that consists of synchronizing estrus with the use of vaginal sponges impregnated with $\mathbf{4 0} \mathrm{mg}$ of fluorogestone acetate followed 12 days later with 500 IU of pregnant mare serum gonadotropin and administered im to the ewe to induce ovulation. Forty-eight $\mathrm{hr}$ later, a ram is introduced for mating for a period of $24 \mathrm{hr}$. The fetal heart is monitored 60 days later to confirm pregnancy. Using such a technique, linear regressions were determined between fetal age and fetal body wt in 44 fetuses, and between fetal age and total kidney wt and between fetal body wt and total kidney wt in 28 fetuses as described by the following equations: fetal wt $(\mathbf{k g})$ $=0.0961 \times$ gestational age (days) -9.2228 coefficient of correlation being $0.85(P<0.001)$; total fetal kidney wt $(\mathrm{g})=0.4729 \times$ gestational age (days) -36.1603 coefficient of correlation being $0.82(P<0.001)$; total fetal kidney wt $(\mathrm{g})=4.9131 \times$ fetal $w t(\mathrm{~kg})$ +8.2478 coefficient of correlation being $0.90(P<0001)$.

\section{SURGICAL PROCEDURES}

The animal care before surgery, anesthesia and surgical procedures used were as described earlier $(18,19)$. Briefly, through a small uterine incision, polyethylene catheters (inside diameter ID $0.86 \mathrm{~mm}$ and outside diameter OD $1.27 \mathrm{~mm}$ ) were inserted into the fetal femoral vein and both femoral arteries for a distance of approximately $5 \mathrm{~cm}$ and secured with silk ligatures. In fetuses younger than 110 days, polyethylene catheters of ID $0.58 \mathrm{~mm}$ and OD $0.965 \mathrm{~mm}$ were inserted. Through the same incision, the umbilical cord was located, the urachus identified and ligated distally, and a $3 \frac{1}{2}$ French infant feeding tube inserted and advanced approximately $4-6 \mathrm{~cm}$ into the fetal bladder. The sight of urine flowing in the catheter indicated that the urachal catheter was well located; the catheter was then closed with a sterile threeway stopcock.

All four catheters were secured with silk ligatures and a drop of methyl-2-cyanoacrylate (Eastman 910 Adhesive, Eastman Chemical Products, Inc.) was applied for tissue adhesion. An additional catheter was also secured in the amniotic cavity for intrauterine pressure recording. Thereafter, the hind limbs were replaced, the fetal membranes, uterine cavity, and abdominal wall were closed in separate layers using 2-0 and 1-0 catgut sutures. All catheters were then exteriorized through a subcutaneous tunnel and placed into a cloth pouch on the animal's flank, after which the abdominal skin was closed. Ampicillin, l'g, was injected into the amniotic cavity at the end of surgery and also administered iv to the ewe 
during surgery. Thereafter, ampicillin, $1 \mathrm{~g}$, was given to the ewe im every $8 \mathrm{hr}$ for the first 3 days after surgery and every time the catheters were flushed.

All vascular catheters were irrigated daily for the first 3 days with a heparinized saline solution and every other day henceforth. When not used, the catheters were filled with heparinized saline solution and sealed with three-way stopcocks.

After surgery, the ewe was kept in a regular stall and fed a standard diet. The animal was usually standing and eating within $1 \mathrm{hr}$ after surgery. A recovery period of at least 6 days was required before any experiments were carried out. Recovery of fetal renal function from the stress of surgery has been demonstrated to take between 3-6 days (8).

\section{PHYSIOLOGIC STUDIES}

During the physiologic studies, the ewe was transferred into a small cart permitting it to stand only. The fetal glomerular filtration rate (GFR) was determined by a constant infusion of $\left[{ }^{125} \mathrm{I}\right]$ iothalamate. A priming dose of $0.45 \mu \mathrm{Ci} / \mathrm{kg}$ of iothalamate was administered followed by a constant infusion of $0.1 \mu \mathrm{Ci} / \mathrm{kg} / \mathrm{min}$ in $5 \%$ dextrose solution at a rate of $0.09 \mathrm{ml} / \mathrm{min}$. An equilibration period of $1 \mathrm{hr}$ was then observed before the start of the first renal clearance period. After the equilibration period, three 20 -min renal clearance periods were determined. At the midpoint of each clearance period arterial blood was obtained for measurement of plasma concentrations of $\left[{ }^{125} I\right]$ iothalamate, sodium, potassium, chloride and urea, plasma osmolality, and arterial blood $\mathrm{pH}$ and blood gases $\left(\mathrm{PCO}_{2}\right.$ and $\left.\mathrm{PO}_{2}\right)$. At the end of each clearance period, urine was collected to determine the urinary excretion rates of urea, sodium, potassium and chloride, urinary osmolality and concentration of $\left[{ }^{125} I\right]$ iothalamate. Individual data from each of the three clearance periods were then averaged to obtain a single value.

In all fetuses, in order to prevent any hemodynamic changes, each fetal blood sample was replaced with an equal amount of maternal blood. In 28 fetal preparations, heart rate, arterial pressure, and amniotic pressure were monitored continuously throughout the studies. All pressures were measured with $\mathrm{P}_{23} \mathrm{Db}$ (Statham Instruments Division, Gould Inc.) pressure transducers. Fetal mean arterial blood pressures (MABP) were registered and reported with respect to correction for amniotic pressure. Fetal heart rate was monitored with a cardiotachometer triggered from the fetal arterial pressure signal. Pressures and heart rate were recorded on a Beckman direct writing recorder. At the end of the experiment, the fetus and ewe were killed separately with lethal doses of $\mathrm{KCl}$ solution. Thereafter, the weight of the fetus and both fetal kidneys were determined.

\section{ANALYTICAL METHODS}

Plasma and urine concentrations of sodium and potassium were determined by flame photometry with a lithium internal standard, concentrations of chloride by potentiometric titration and concentrations of $\left[{ }^{125} \mathrm{I}\right]$ iothalamate by gamma emission of $\left[{ }^{125} \mathrm{I}\right]$ in a Beckman gamma spectrometer (Beckman Gamma 300 System, Beckman Co., Creve Coeur, MO). Osmolality in plasma and urine was measured with a freezing-point osmometer. Chemical urea determinations were established with an autoanalyzer (Technicon). Hematocrit was measured by micromethod. Glomerular filtration rate was calculated as the clearance of $\left[{ }^{125} \mathrm{I}\right]$ iothalamate. Blood for measurement of $\mathrm{pH}, \mathrm{PCO}_{2}$, and $\mathrm{PO}_{2}$ was collected anaerobically in heparinized glass syringes and immediately processed using appropriate electrodes (Radiometer PHM 72 MK2 acid-base analyzer, Radiometer Co., Denmark).

\section{CALCULATIONS AND DATA ANALYSIS}

The osmolar clearance (Cosm) was determined as follows: Cosm $(\mathrm{ml} / \mathrm{min})=($ Uosm $\cdot \mathrm{V}) /$ Posm, in which Uosm and Posm represent urine and plasma osmolality in mosm $/ \mathrm{kgH}_{2} \mathrm{O}$ and $\mathrm{V}$ the urinary flow rate in $\mathrm{ml} / \mathrm{min}$. The solute-free water clearance
$\left(\mathrm{C}_{\mathrm{H}, \mathrm{O}}\right)$ was calculated as the difference between the urine flow $(\mathrm{V})$ and the osmolar clearance Cosm: $\mathrm{C}_{\mathrm{H}_{2} \mathrm{O}}=\mathrm{V}-$ Cosm.

Analysis of variance using the F-distribution was applied to test the means between different groups of data. The Student $t$ test for unpaired observations was used to compare the difference between means of two populations of different size. The regression lines were determined with the least-squares formula. The term "significant" was used throughout the paper to describe changes with $P$ value of less than 0.05 in a two-sided significance limit. The results are presented as mean $\pm \mathrm{SE}$.

\section{RESULTS}

The mean arterial blood values for $\mathrm{pH}$, blood gases $\left(\mathrm{PCO}_{2}\right.$ and $\left.\mathrm{PO}_{2}\right)$, plasma electrolyte concentrations $\left(\mathrm{Na}^{+}, \mathrm{K}^{+}\right.$, and $\left.\mathrm{Cl}^{-}\right)$, plasma urea, plasma osmolality, and hematocrit are presented in Table 1. No significant changes in any of these parameters were seen in individual fetuses, after three consecutive blood samples at 20-min intervals each. In 28 fetuses ranging from 106-142 days of gestational age, MABP was significantly correlated with fetal age $(r=0.75, P<0.001)$ : MABP was $43.7 \pm 1.7 \mathrm{mmHg}$ in fetuses less than 120 days, $49.3 \pm 1.3$ in fetuses between 120-130 days and $53.4 \pm 1.39$ in fetuses over 130 days. A significant negative correlation was found between the fetal age and the fetal heart rate $(r=-0.53, P<0.005)$. The mean fetal heart rate values in fetuses of less than 120 days, between 120-130 days and over 130 days were, respectively, $194 \pm 8.8,182 \pm 3.6$, and $162 \pm 5.7$ beats/ $\min$.

Table 2 shows the mean urinary values in three groups of fetuses divided according to gestational age. Using an analysis of variance, no significant difference in urinary flow rate was found between the three groups of fetuses $(\mathrm{F}=2.18, P>0.1)$. However, by nonpaired $t$ test, urinary flow rate increased significantly $(P<$ 0.01 ) when fetuses of less than 120 days were compared to fetuses between 120-130 days, but not to fetuses over 130 days. A significant positive correlation was found between fetal age and fetal GFR expressed as iothalamate clearance (Cioth) in $\mathrm{ml} / \mathrm{min}$ $(r=0.60, P<0.001)$. Similarly, Cioth $(\mathrm{ml} / \mathrm{min})$ was closely correlated to fetal kidney wt $(r=0.73, P<0.001)$. No significant correlation was found between fetal GFR corrected for body wt $(\mathrm{ml} / \mathrm{min} / \mathrm{kg})$ or kidney wt $(\mathrm{ml} / \mathrm{min} / \mathrm{g})$ and gestational age; the correlation coefficient being -0.08 and 0.31 , respectively. A $35 \%$ increase in urinary osmolality (Uosm) was found in fetuses over 130 days when compared to younger fetuses. This increase in

Table 1. Arterial blood and hemodynamics values

\begin{tabular}{|c|c|c|c|}
\hline & $\overline{\mathrm{X}}$ & SE & $n$ \\
\hline $\mathrm{pH}$ & 7.36 & 0.007 & 44 \\
\hline $\begin{array}{l}\mathrm{PCO}_{2} \\
\quad \mathrm{~mm} \mathrm{Hg}\end{array}$ & 45.10 & 0.78 & 44 \\
\hline $\begin{array}{l}\mathrm{PO}_{2} \\
\quad \mathrm{~mm} \mathrm{Hg}\end{array}$ & 22.08 & 0.49 & 44 \\
\hline $\begin{array}{l}\mathrm{Na}^{+} \\
\mathrm{mEq} / \text { liter }\end{array}$ & 146 & 0.47 & 44 \\
\hline $\mathrm{K}^{+} \mathrm{mEq} /$ liter & 4.15 & 0.04 & 44 \\
\hline $\begin{array}{l}\mathrm{Cl}^{-} \\
\mathrm{mEq} / \text { liter }\end{array}$ & 105 & 0.65 & 37 \\
\hline $\begin{array}{l}\text { Urea } \\
\qquad \mathrm{mg} / 100 \mathrm{ml}\end{array}$ & 34.5 & 2.01 & 44 \\
\hline $\begin{array}{l}\text { Osmolality } \\
\text { mosm } / \mathrm{kg} \mathrm{H} \mathrm{H}_{2} \mathrm{O}\end{array}$ & 292 & 1.06 & 44 \\
\hline $\begin{array}{l}\text { Hematocrit } \\
\quad \%\end{array}$ & 33.7 & 0.90 & 30 \\
\hline $\begin{array}{l}\text { MABP } \\
\text { mm Hg }\end{array}$ & 49.8 & 1.22 & 28 \\
\hline $\begin{array}{l}\text { Heart Rate } \\
\text { beats } / \mathrm{min}\end{array}$ & 178 & 4.66 & 28 \\
\hline
\end{tabular}

'MABP: mean arterial blood pressure. $n$ : number of animals. 
Table 2. Clearance data in groups of fetuses of different gestational age

\begin{tabular}{|c|c|c|c|c|c|}
\hline & $<120$ days & $120-130$ days & $>130$ days & $\mathrm{F}$ & $\mathbf{P}$ \\
\hline $\mathrm{V} \mathrm{ml} / \mathrm{min}$ & $0.46 \pm 0.10$ & $0.79 \pm 0.12$ & $0.62 \pm 0.10$ & 2.18 & NS \\
\hline C ioth $\mathrm{ml} / \mathrm{min}$ & $1.70 \pm 0.25$ & $2.88 \pm 0.47$ & $3.56 \pm 0.41$ & 6.66 & 0.01 \\
\hline$(\mathrm{U} / \mathrm{P})$ ioth & $4.77 \pm 0.92$ & $3.88 \pm 0.44$ & $8.25 \pm 1.53$ & 4.09 & 0.05 \\
\hline \multicolumn{6}{|l|}{ Uosm } \\
\hline $\operatorname{mosm} / \mathrm{kg} \mathrm{H}, \mathrm{O}$ & $158 \pm 12.4$ & $161 \pm 13.8$ & $245 \pm 28.2$ & 5.75 & 0.01 \\
\hline (U/P)osm & $0.54 \pm 0.04$ & $0.55 \pm 0.04$ & $0.83 \pm 0.09$ & 5.77 & 0.01 \\
\hline$(\mathrm{U} / \mathrm{P})$ urea & $3.62 \pm 0.54$ & $3.00 \pm 0.31$ & $6.79 \pm 1.19$ & 7.20 & 0.01 \\
\hline$(\mathrm{U} / \mathrm{P}) \mathrm{Na}^{+}$ & $0.39 \pm 0.04$ & $0.41 \pm 0.03$ & $0.41 \pm 0.05$ & 0.09 & NS \\
\hline$(\mathrm{U} / \mathrm{P}) \mathrm{Cl}$ & $0.26 \pm 0.05$ & $0.33 \pm 0.03$ & $0.23 \pm 0.03$ & 1.20 & NS \\
\hline$(\mathrm{U} / \mathrm{P}) \mathrm{K}^{+}$ & $2.02 \pm 0.59$ & $2.41 \pm 0.42$ & $7.23 \pm 1.67$ & 5.93 & 0.01 \\
\hline
\end{tabular}

' 14 fetuses were less than 120 days, 13 between 120-130 days, and 17 over 130 days. For (U/P)Cl' there were, respectively, 12,9 , and 16 fetuses. V, urinary flow rate: $C_{\text {loth }}$, iothalamate clearance.

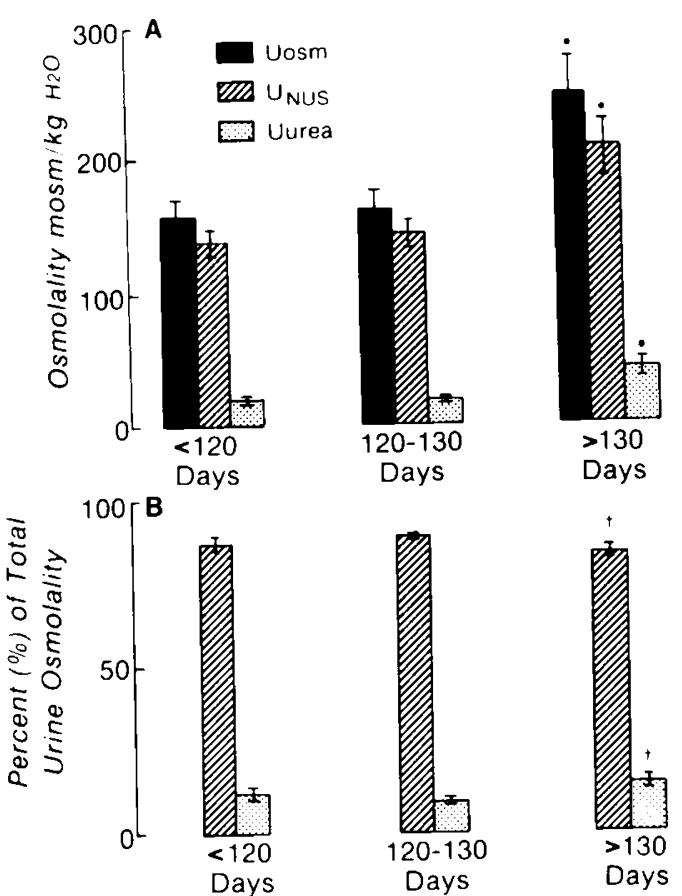

Fig. 1. A: Fetal urine composition at different gestational ages. Uosm, urine osmolality; $\mathrm{U}_{\mathrm{N} u \mathrm{~s}}$, urine nonurea solute; $\mathrm{U}_{\text {urea }}$ urine urea. ${ }^{*}$ for $P<$ 0.05 when fetuses over 130 days are compared either to fetuses $<120$ days or between 120-130 days. $B$ : Percent of urea (Uurea) and nonurea solute ( $U_{N(\text { IS })}$ to total urine osmolality. $\dagger$ for $P<0.02$ when fetuses $>130$ days are compared to fetuses between $120-130$ days.

Uosm was paralleled by significant increases in $(\mathrm{U} / \mathrm{P})$ iothalamate and $(\mathrm{U} / \mathrm{P})$ osm. In 5 of 17 fetuses over 130 days, the $(\mathrm{U} / \mathrm{P})$ osm ratio was over 1.0 , indicating hyperosmotic urine in respect to plasma. An increase in $(\mathrm{U} / \mathrm{P})$ urea ratio was also found in fetuses over 130 days. This increase in $(\mathrm{U} / \mathrm{P})$ urea ratio correlated closely with the increase in $(\mathrm{U} / \mathrm{P})$ ioth $(r=0.87, P<0.001)$ and represented predominantly an increase in glomerular filtration. A significant positive correlation was found between Cioth and urea clearance $(r=0.84, P<0.001)$; the mean value for urea clearance was $80 \%$ of the mean value for Cioth.

The (U/P) values for $\mathrm{Na}^{+}$and $\mathrm{Cl}^{-}$were not correlated to fetal age. In constrast, $(\mathrm{U} / \mathrm{P}) \mathrm{K}^{+}$ratio increased significantly after 130 days and in 6 of 17 animals, individual $(\mathrm{U} / \mathrm{P}) \mathrm{K}^{+}$ratios were superior to $(U / P)$ ioth ratios indicating secretion of $K^{+}$by the fetal tubule.

The osmotic composition of fetal urine at different gestational ages is presented in Figure 1. Figure 1-A demonstrates that after 130 days the increase in Uosm concentration is secondary to a parallel increase in urea (Uurea) and nonurea solute ( $\mathbf{U}_{\text {Nus }}$ ) concentrations. The percent of Uurea and $\mathrm{U}_{\mathrm{Nus}}$ to total urine osmolality is shown in Figure 1-B. It is demonstrated that after
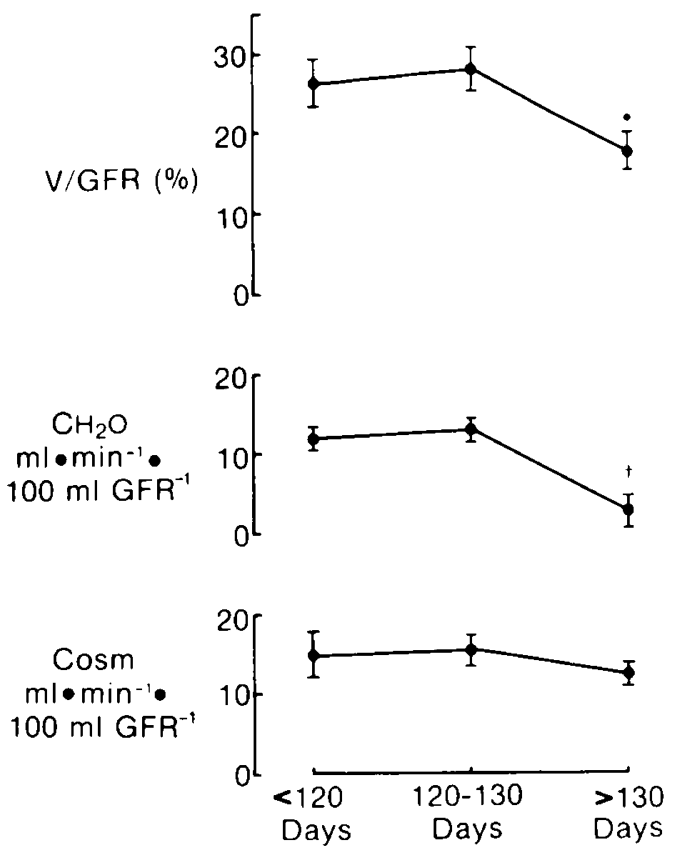

Fig. 2. Summary of fetal osmolar and water clearances at different gestational ages. V/GFR, fractional water excretion in $\% ; \mathrm{C}_{\mathrm{H}_{2} \mathrm{O}} / \mathrm{GFR}$, free water clearance corrected for $100 \mathrm{ml}$ GFR; Cosm/GFR, osmolar clearance corrected for $100 \mathrm{ml} \mathrm{GFR.}{ }^{*}$ for $P<0.05$ and $\dagger$ for $P<0.01$ when fetuses $>130$ days are compared either to fetuses $<120$ days or between $120-130$ days.

130 days there is a small increase in the relative contribution of Uurea to the total urinary osmotic load. However, this increase $(5 \%)$ is only significant $(P<0.02)$ when fetuses over 130 days and those between 120-130 days are compared.

Values for fractional water excretion (V/GFR), free water clearance $\left(\mathrm{C}_{\mathrm{H}, \mathrm{O}} / \mathrm{GFR}\right)$ and osmolar clearance $(\mathrm{Cosm} / \mathrm{GFR})$ are presented in Figure 2. The results are presented in relation to GFR rather than in absolute value in order that maturational changes in GFR do not obscure the changes in tubular water reabsorption. The percent of filtered water excreted (V/GFR) was high before 120 days of gestation $(26.8 \pm 3.04 \%)$ and remained elevated in fetuses of $120-130$ days $(28.7 \pm 2.53 \%)$. After 130 days of gestation V/GFR decreased significantly $(P<0.05)$ to $18.3 \pm$ $2.56 \%$. Similarly, no significant changes in free water clearance were found between the two groups of fetuses before 130 days of gestation; $\mathrm{C}_{\mathrm{H}_{2} \mathrm{O}} / \mathrm{GFR}$ values being, respectively, $12.02 \pm 1.53 \mathrm{ml} /$ $\mathrm{min} / 100 \mathrm{ml} \mathrm{GFR}$ up to 120 days and $13.18 \pm 1.46 \mathrm{ml} / \mathrm{min} / 100$ ml GFR between $120-130$ days. After 130 days $\mathrm{C}_{\mathrm{H}, \mathrm{O}} / \mathrm{GFR}$ decreased significantly $(P<0.01)$ to $5.82 \pm 1.97 \mathrm{ml} / \mathrm{min} / 100 \mathrm{ml}$ GFR. Osmolar clearance values (Cosm/GFR) remained unchanged during the last third of gestation; values being, respectively, $14.76 \pm 2.57$ for fetuses less than 120 days, $15.49 \pm 1.90$ 
between $120-130$ days and $12.51 \pm 1.34 \mathrm{ml} / \mathrm{min} / 100 \mathrm{ml} \mathrm{GFR}$ in fetuses over 130 days.

\section{DISCUSSION}

The hypotonicity of fetal urine in respect to plasma is a well accepted entity. Previous investigations using sheep $(3,8,23)$, monkeys (6), pigs (13), rabbits (13), and guinea pigs $(5,15)$ all agreed that fetal urine osmolality is hypotonic when compared to plasma values. Alexander et al. (3), using exteriorized fetal lamb preparations, suggested that before 130 days of gestation, fetal urine is always hypotonic when, subsequently, urine may become hypertonic. Gresham et al. (8), using chronically catheterized fetal lambs and studying them from 117 days of gestation until term, demonstrated that during the recovery period after surgery (3-6 days), urinary flow rate and osmolality fluctuated widely and, in some animals, urine became hypertonic. Thereafter, urine flow stability was achieved and urine osmolality came back to hypotonic values until the beginning of parturition. These previous results, therefore suggest, that fetal urine remains hypotonic during the last third of gestation unless the fetus is submitted to stressful conditions $(3,8)$ (surgery or exteriorization from the uterus) in which urine osmolality may become hypertonic. However, those studies do not indicate if reabsorption of free water is stable or increased during gestation when the fetus is kept in physiologic conditions.

In the present study, a recovery period of at least 6 days was allowed in order to reduce the effect of surgery and anesthesia on the fetal renal function. Using this protocol, our previous studies $(18,19)$ were confirmed showing that fetal GFR expressed in $\mathrm{ml} /$ min increases with fetal age, whereas GFR corrected for body wt $(\mathrm{ml} / \mathrm{min} / \mathrm{kg})$ or kidney $\mathrm{wt}(\mathrm{ml} / \mathrm{min} / \mathrm{g})$ remains stable during the last trimester of gestation. It was also found, contrary to the study by Gresham et al. (8), that mean urine osmolality values (Uosm) remained stable at about $160 \mathrm{mosm} / \mathrm{kg}_{\mathrm{H}_{2} \mathrm{O}}$ until 130 days of gestation and then increased to $245 \pm 28.2 \mathrm{mosm} / \mathrm{kg}_{\mathrm{H}_{2} \mathrm{O}}$ (Table 2). Such differences between the present study and the study of Gresham et al. (8) remains unexplained; however, in the latter study (8), only four fetuses over 130 days of gestation were studied after recovering from surgery, whereas in the present study Uosm was measured in 17 fetuses after 130 days of gestation. Finally, we demonstrated that reabsorption of free water by the fetal kidney increased after 130 days of gestation.

In the present study, Cosm/GFR does not change and both V/ GFR and $\mathrm{C}_{\mathrm{H}_{2} \mathrm{O}} / \mathrm{GFR}$ (Fig. 2) decrease significantly. Because V/ GFR is determined by the sum of $C_{H, O} / G F R$ and Cosm/GFR $\left(\mathrm{V} / \mathrm{GFR}=\mathrm{C}_{\mathrm{H}_{2} \mathrm{O}} / \mathrm{GFR}+\mathrm{Cosm} / \mathrm{GFR}\right)$, a decrease in V/GFR not accompanied by changes in Cosm/GFR must be secondary to a decrease in $\mathrm{C}_{\mathrm{H}, \mathrm{O}}$ /GFR or, in other words, to an increase in free water reabsorption. In the present study, there is a parallel decrease in $\mathrm{V} / \mathrm{GFR}$ and $\mathrm{C}_{\mathrm{H}_{0} \mathrm{O}} / \mathrm{GFR}$ in fetuses over 130 days without any significant changes in Cosm/GFR confirming that the decrease in V/GFR is secondary to an increase in free water reabsorption. Moreover, the absence of significant changes in $(\mathrm{U} / \mathrm{P}) \mathrm{Na}^{+}$and $(\mathrm{U} / \mathrm{P}) \mathrm{Cl}^{-}$ratios during the last third of gestation is against the development of an osmotic diuresis in fetuses over 130 days as an explanation for the rise in fetal Uosm. Therefore, the increase in Uosm concentration in fetuses over 130 days, even if it does not reach values hypertonic to plasma in all fetuses, represents an increase in reabsorption of free water by the collecting tubule of those animals.

This increase in reabsorption of free water in near-term fetuses may represent either an increase in collecting tubule permeability to water, or an increase in the cortex to papilla solute gradients or both.

An increase in collecting tubule permeability to water may signify either an increase in circulating endogenous plasma arginine vasopressin (AVP) or in end-organ responsiveness to arginine vasopressin. There is no evidence that fetal plasma AVP concentration increases during the last trimester of gestation. On the contrary, mean plasma AVP concentrations in fetuses of 121-141 days of gestation tend to be lower than mean values between 101120 days (27). Moreover, the osmoreceptor and volume receptor control system of AVP release in the fetus are essentially mature during the last trimester of gestation $(20,27)$ and, thus, argue against a defect in secretion of vasopressin. Therefore, if the rise in reabsorption of free water in fetuses over 130 days is secondary to an increase in the water permeability of the fetal collecting tubule, it has to be attributed to an increase in end-organ responsiveness to arginine vasopressin. In favor of this latter hypothesis, recent studies from our laboratory indicate that in vivo infusion of exogenous AVP in chronically catheterized fetal lambs initiated an increase in absolute free water reabsorption in fetuses older than 120 days of gestation, but not in younger fetuses (21), therefore, suggesting that the collecting tubule of near-term fetuses, under vasopressin stimulation, is more permeable than earlier in gestation.

One can thus speculate that the increase in free water reabsorption in near-term fetuses found in the present study is secondary to either an increase in binding sites for vasopressin or to the maturation process involving the vasopressin-responsive cyclic AMP system or both. Studies from neonatal kidneys of both rats and rabbits indicated that the activation of collecting tubule adenyl cyclase by vasopressin is decreased in neonates when compared to adults (22). Moreover, Rajerison $e t$ al. (17) found that vasopressin binding capacity of rat tubule membranes increased after birth. Finally, it is also possible that prostaglandins $\mathrm{E}_{2}$ found in high concentration in fetal lamb urine (26) may inhibit the action of vasopressin on the collecting tubule. However, there are arguments against changes in end-organ responsiveness (collecting tubule) to arginine vasopressin. Abramow and Dratwa (1), using the isolated tubule perfusion technique, demonstrated that the collecting duct of a human fetal kidney ( $5 \frac{1 / 2}{2}$ month old) had well developed receptors for arginine vasopressin, suggesting that the diminished renal concentrating ability of the immature kidney when compared to the adult's reflects a diminished osmotic gradient in the medulla as suggested previously (7).

Therefore, the structural immaturity of the fetal medulla characterized by short loops of Henle (24) and the increased blood flow to the medulla $(4,11,16)$ appear to be major factors regulating the fetal medulla as a counter current multiplier. In the immature kidney, because the blood flow is mainly distributed to the juxtamedullary glomeruli whose efferent arterioles supply the vasa recta of the medulla, it is possible that a high flow of blood through the vasa recta may either prevent or disperse the intrarenal solute gradient normally formed in the medulla. Moreover, the low GFR present during fetal life may reduce the amount of solutes, especially urea, to be delivered distally. In the present study, the clearance of urea is low during fetal life and closely follows the GFR $(r=0.84)$. This low rate of urea clearance and the small proportion of urinary solute consisting of urea in fetuses of all age groups (Fig. 1) may limit the formation of an osmotic gradient in the inner medulla of the fetal kidney. Under these conditions, free water reabsorption by the fetal kidney will depend mainly on the active transport of chloride by the thick ascending limb of Henle and water reabsorption in the outer medulla. The mechanisms involved in the buildup of an osmotic gradient between the corticomedullary junction and the papillary have been recently reviewed by Jamison and Maffly (9) and Kokko (12).

In summary, it was demonstrated in chronically catheterized fetal lambs that there is an increase in free water reabsorption in late gestation (over 130 days). It also suggests that both an increase in end-organ responsiveness and maturation of the mechanisms involved in the buildup of an osmotic gradient in the fetal medulla may have a major role in the increase of free water reabsorption in near-term fetuses.

\section{REFERENCES AND NOTES}

1. Abramow, M.. and Dratwa, M.: Effect of vasopressin on the isolated human collecting duct. Nature, 250: 492 (1974)

2. Ainsworth. L., Hackett, A. J., Heaney. D. P., Langford, G. A., and Peters, H. F.: 
A multidisciplinary approach to the development of controlled breeding and intensive production systems for sheep. Symposium: Management of Reproduction in Sheep and Goats. p. 101-108. (Madison. Wisconsin. July 24. 1977)

3. Alexander, D. P.. Nixon. D. A.. Widdas, W. F., and Wohlzogen, F. X.: Renal function in the sheep fetus. J. Physiol., 140: 14 (1958).

4. Aschinberg, L. C.. Goldsmith, D. I.. Olbing. H., Spitzer, A., Edelmann, C. M.. $J_{r}$, and Blaufox. M. D.: Neonatal changes in renal blood flow distribution in puppies. Am. J. Physiol.. 228: 1453 (1975).

5. Boylan, J. W., Colbourn, E. P., and McCance, R. A.: Renal function in the foetal and newborn guinea pig. J. Physiol., 141: 323 (1958).

6. Chez, R. A.. Smith. F. G., and Hutchinson, D. L.: Renal function in the intrauterine primate fetus. Amer. J. Obstet. Gynecol.. 90: 128 (1964).

7. Edelmann, C. M., Barnett, H. L.. and Troupkou, V.: Renal concentrating mechanisms in newborn infants. Effect of dietary protein and water content. role of urea, and responsiveness to antidiuretic hormone. J. Clin. Invest., 39 $1062(1960)$.

8. Gresham. E. L.. Rankin, J. H. G.. Makowski, E. L., Meschia, G., and Battaglia F. C.: An evaluation of fetal renal function in a chronic sheep preparation. J. Clin. Invest.. 51: 149 (1972).

9. Jamison, R. L., and Maffly, R. H.: The urinary concentrating mecnanism. N Engl. J. Med., 295: 1059 (1976).

10. Jennings, J. J., and Crowley, J. P.: The influence of mating management on fertility in ewes following progesterone-PMS treatment. Vet. Rec.. 90: 495 (1972).

11. Jose. P. A., Logan, A. G.. Slotkoff, L. M., Lilienfield. L. S., Calcagno, P. L., and Eisner, G. M.: Intrarenal blood flow distribution in canine puppies. Pediatr. Res., 5: 335 (1975).

12. Kokko, J. P.: The role of the renal concentrating mechanisms in the regulation of serum sodium concentration. Amer. J. Med., 62: 165 (1977).

13. McCance, R. A., and Stanier, M. W.: The function of the metanephros of foetal rabbits and pigs. J. Physiol., 151: 479 (1960).

14. McCance. R. A., and Widdowson, E. M.: Renal function before birth. Proc. Roy Soc. (London), 141: 488 (1953).

15. Merlet-Benichou, C., de Rouffignac, C.: Renal clearance studies in fetal and young guinea pigs: effect of salt loading. Amer. J. Physiol., 232: FI78 (1977).

16. Olbing. H., Blaufox, M. D., Aschinberg, L. C., Silkalns, G. 1., Bernstein, J., Spitzer, A., and Edelmann, C. M.. Jr.: Postnatal changes in renal glomerular blood flow distribution in puppies. J. Clin. Invest.. 52: 2885 (1973).

17. Rajerison, R. M.. Butlen. D., and Jard, S.: Ontogenic development of antidiuretic

Copyright $(\subset) 1979$ International Pediatric Research Foundation, Inc $0031-3998 / 79 / 1310-1172 \$ 02.00 / 0$ hormone receptors in rat kidney: comparison of hormonal binding and adenylate cyclase activation. Mol. Cellular Endocrinol., 4: 271 (1976).

18. Robillard, J. E. Sessions, C.. Kennedy, R. L., Robillard, L. H., and Smith. F. G. Jr.: Interrelationship between glomerular filtration rate and renal transport of sodium and chloride during fetal life. Amer. J. Obstet. Gynecol., 128: 727 (1977).

19. Robillard, J. E., Sessions, C., Kennedy, R. L.. and Smith. F. G. Jr.: Maturation of the glucose transport process by the fetal kidney. Pediatr. Res.. 12: 680 (1978).

20. Robillard, J. E.. Weitzman, R., Fisher, D. A., and Smith. F. G. Jr.: The dynamics of vasopressin release and blood volume regulation during fetal hemorrhage in the lamb fetus. Pediatr. Res., 13: 606 (1979).

21. Robillard, J. E., Weitzman. R. E., and Smith. F. G. Jr.: Presence of functioning vasopressin receptors in the fetal kidney. Pediatr. Res., (abstr) 12: 547 (1978).

22. Schlondorff. D., Weber. H., Trizna. W., and Fine. L. G.: Vasopressin responsiveness of renal adenylate cyclase in newborn rats and rabbits. Amer. J. Physiol., 234: F16 (1978).

23. Smith, F G Adams, F. H. Borden, M.. and Hilburn. J.: Studies of renal function in the intact fetal lamb. Amer. J. Obstet. Gynecol., 96: 240 (1966).

24. Speller, A. M., and Moffat, D. B.: Tubulo-vascular relationships in the developing kidney. J. Anat., 123: 487 (1977).

25. Stanier, M. W.: Development of intra-renal solute gradients in foetal and postnatal life. Pflugers Arch., 336: 263 (1972).

26. Walker, D. W., and Mitchell, M. D.: Prostaglandins in urine of foetal lambs. Nature, 271: 161 (1978).

27. Weitzman, R. E., Fisher, D. A., Robillard. J., Erenberg, A., Kennedy. R. L.. and Smith, F.: Arginine vasopressin response to an osmotic stimulus in the fetal sheep. Pediatr. Res., 12: 35 (1978).

28. The authors thank Mrs. Marilyn Simpson for assistance in the preparation of this manuscript.

29. This research was supported by research grants HD-11466 and HD-08953 from the National Institute of Child Health and Human Development. Dr. J. E. Robillard is the recipient of a Research Career Development Award \#HD. 00254. Dr. J. Matson is the recipient of a Pharmaceutical Manufacturers Association Research Fellowship.

30. Requests for reprints should be addressed to: Jean E. Robillard, MD. Departmen of Pediatrics. University of lowa Hospitals. lowa City, lowa 52242 (USA).

31. Received for publication August 28, 1978

32. Accepted for publication November 15, 1978 